\title{
Saturniid moths (Lepidoptera: Bombycoidea) from an Atlantic Rain Forest fragment in southeastern Brazil
}

\author{
FABIANO F. ALBERTONI ${ }^{1}$, CARLOS G.C. MIELKE ${ }^{2}$ and MARCELO DUARTE ${ }^{1}$ \\ ${ }^{1}$ Programa de Pós-Graduação em Sistemática, Taxonomia Animal e Biodiversidade, Museu de Zoologia \\ da Universidade de São Paulo, Avenida Nazaré, 481, 04263-000 São Paulo, SP, Brazil \\ ${ }^{2}$ Avenida dos Pioneiros, 1494, 84145-000 Carambeí, PR, Brazil
}

Manuscript received on August 11, 2017; accepted for publication on January 15, 2018

\begin{abstract}
The light-attracted silk moths (Lepidoptera: Saturniidae) of the Boraceia Biological Station in the municipality of Salesópolis, state of São Paulo, southeastern Brazil have been sampled over more than seven decades (1942-2013). A total of 6,288 individuals (including a gynandromorph) belonging to five subfamilies, 46 genera and 133 species were identified. Hemileucinae was the most abundant and speciesrich subfamily, followed by Ceratocampinae, Arsenurinae, Saturniinae, and Oxyteninae. Hylesia Hübner, Automeris Hübner, and Dirphiopsis Bouvier (Hemileucinae) were the dominant genera in abundance and species richness. Only Automeris illustris (Walker), Gamelia remissoides Lemaire, and Hidripa paranensis (Bouvier) (Hemileucinae) were recorded in all months of sampling. Hylesia metapyrrha (Walker) was the most abundant saturniid species recorded at the station, with 375 specimens, followed by Hylesia oratex Dyar with 265 specimens, Dirphia muscosa Schaus with 261 specimens (all Hemileucinae); Copaxa canella Walker (Saturniinae) with 232 specimens, and Lonomia cf. obliqua Walker (Hemileucinae) with 106 specimens. Fifteen additional species were each represented by more than 100 specimens. The importance of the Boraceia Biological Station to the maintenance of the saturniid moth diversity in the Atlantic Forest is discussed.
\end{abstract}

Key words: conservation, inventory, neotropical, phenology, research promotion, silk moths.

\section{INTRODUCTION}

Moths and butterflies are important organisms in tropical ecosystems because they interact widely with the vegetation and local fauna (Gilbert 1984, Miller 1993, Bonebrake et al. 2010, Johnson et al. 2017, Goldstein 2017). Their feeding habits, great diversity, ease of sampling, and the relatively well known taxonomy of some groups, such as

Correspondence to: Marcelo Duarte

E-mail: mduartes@usp.br
Saturniidae, make them potentially important organisms for use in monitoring the biological diversity in different communities (Brown and Freitas 1999, 2000a, b, Basset et al. 2017, Mitter et al. 2017).

Saturniidae is comprised of 2,349 species worldwide in 169 genera, and is the most speciesrich family of Bombycoidea (van Nieukerken et al. 2011). Saturniidae has been divided into nine subfamilies: Agliinae, Arsenurinae, Ceratocampinae, Cercophaninae, Hemileucinae, 
Ludiinae, Oxyteninae, Salassinae, and Saturniinae (Minet 1994, Regier et al. 2008, van Nieukerken et al. 2011). Of these, five are represented in the Brazilian fauna (Lemaire and Minet 1998, Duarte et al. 2012): the most speciose subfamily, Hemileucinae, consists of 630 species in 51 genera; the cosmopolitan Saturniinae is represented by 480 species in 59 genera; Ceratocampinae has 170 species in 27 genera; and the Neotropical endemic Arsenurinae and Oxyteninae are represented by 60 species in 10 genera and 35 species in three genera, respectively (Lemaire and Minet 1998). More than one-third of the species estimated for Saturniidae occur in the Neotropics (Lemaire and Minet 1998, Duarte et al. 2012). In Brazil, approximately 500 species have been recorded (Camargo et al. 2017). Recently, over 500 saturniid species from the Neotropics were described by Brechlin and Meister in the journal Entomo-Satsphingia, which would add many species to the family, despite these authors' dubious method of splitting previous available names into cryptic groups (Nässig et al. 2010, St. Laurent et al. 2015).

Adult saturniid moths are mostly nocturnal, except for males of several species in Saturniinae, Hemileucinae, Agliinae, and Ceratocampinae (e.g., Anisota spp., see also Lemaire and Minet 1998). The females of Heliconisa Walker, 1855 are essentially diurnal, as well as the females of Ithomisa Oberthür, 1881, which fly at the end of the day and also at night. The mouthparts of these insects are inchoate and they do not feed during their short 5-12-day adult life (Janzen 1984). Strong sexual dimorphism is observed in species of Ceratocampinae, Hemileucinae, and Oxyteninae; females can weigh more than twice as much as males, usually bear filiform antennae (pectinate in males), and are larger with more rounded wings than in males (Janzen 1984).

\section{BRAZILIAN INVENTORIES OF SATURNIIDAE}

The southern states of Brazil, Rio Grande do Sul, Santa Catarina, and Paraná, have partially inventoried their saturniid fauna. After approximately a decade of investigations in Rio Grande do Sul, 113 species in four subfamilies were recorded: Hemileucinae (61 species, 54\%), Ceratocampinae (30, 27\%), Arsenurinae (12,11\%), and Saturniinae (10,9\%) (Nunes et al. 2004, Specht et al. 2005a, b, Prestes et al. 2009). Although we have some efforts of sampling in Rio Grande do Sul, mainly focusing on groups of medical importance, there is still a need for long-term and systematic inventories to know the composition and distribution of the saturniids in different vegetation formations (e.g., grasslands, dense ombrophilous and seasonal deciduous forests, Araucaria forest) in this region of Brazil (see also vegetation map of Buriol et al. 2007).

To determine the Santa Catarina saturniid fauna, Siewert et al. (2010) used data from six important Brazilian lepidopteran collections, as well as geographic distributions provided by Lemaire (1978, 1980, 1988, 2002). They recorded a total of 149 species in 50 genera, including $90(60 \%)$ species of Hemileucinae, $32(21 \%)$ of Ceratocampinae, 16 (11\%) of Arsenurinae, and 11 (7\%) of Saturniinae. We can state that the saturniid fauna of Santa Catarina is still poorly sampled. Only eight municipalities in the entire state have been sampled to date (see the map in Siewert et al. 2010), and it is necessary to intensify sampling efforts in the main vegetation formations in the state (e.g., deciduous, dense ombrophilous, and subtropical ombrophilous forests).

Knowledge of the lepidopteran fauna of Paraná is certainly the most extensive of the southern states of Brazil. However, with regard to the saturniids, long-term surveys of these moths have intensified only recently. During an entomological survey conducted between 1986 and 1987 in 
eight localities in Paraná, Marinoni and Dutra (1991) sampled different groups of Lepidoptera with malaise and light traps (modified from the "Luiz de Queiroz" model light trap; see Silveira Neto and Silveira 1969). The saturniids were studied by Marinoni et al. (1997), resulting in the identification of 83 species distributed as follows: Hemileucinae (38 species, $46 \%$ of all species sampled), Ceratocampinae (25, 30\%), Arsenurinae $(10,12 \%)$, Saturniinae $(9,11 \%)$, and Oxyteninae (1, 1\%). More recently, Santos et al. (2015) sampled the community of Saturniidae in a montane mixed ombrophilous forest in the eastern part of the state (Vossoroca, Tijucas do Sul, 25 $5^{\circ} 50^{\prime} 08.93$ 'S, $49^{\circ} 02$ '55.20"W, elevation $880 \mathrm{~m}$ ). They used black and mercury-vapor mixed bulbs, and identified 86 species of saturniids: Hemileucinae (56 species, $65 \%$ of all species sampled), Ceratocampinae (17, $20 \%$ ), Arsenurinae (5, 6\%), Saturniinae (7, 8\%), and Oxyteninae $(1,1 \%)$. We believe that a greater collecting effort in poorly sampled localities in Paraná will expand the list of species currently recorded from the nine localities sampled to date.

The saturniid fauna in the Cerrado (Brazilian savanna) has been documented by Camargo and Becker (1999) and A. Camargo et al. (unpublished data). Data from several entomological collections in Brazil were extensively searched. As a result, 202 species from 74 localities in 10 states and the Federal District were recorded (A. Camargo et al., unpublished data). Of these, 119 (58.9\%) were Hemileucinae, 48 (23.7\%) Ceratocampinae, 22 (10.9\%) Arsenurinae, 11 (5.4\%) Saturniinae, and 2 (1\%) Oxyteninae. Of the six terrestrial biomes in Brazil (Amazon Forest, Atlantic Forest, Cerrado, Caatinga, Pampa, and Pantanal; see also Instituto Brasileiro de Geografia e Estatística 2004), the Cerrado is the second largest. This biome covers approximately $2,000,000 \mathrm{~km}^{2}$, with a continuous distribution throughout the entire Central-West region, western Bahia and Minas Gerais, as well as disjunct distribution areas in northern and northeastern São Paulo and northern Paraná (Filardi et al. 2007). The Cerrado borders three other biomes and is considered a world biodiversity hotspot (Myers et al. 2000). Although extensive efforts have been made to sample saturniids in the Brazilian Cerrado, these moths remain little known in some states that still contain remnants (strongly threatened by human action) of this biome.

In addition, as part of an extensive entomological catalog, Zikán and Zikán (1968) listed the lepidopteran (not all suborders) fauna from the Itatiaia region, which included the family Saturniidae (Saturnioidea in Zikán and Zikán 1968). This region is located between the states of Rio de Janeiro and Minas Gerais and varies widely in altitude, from approximately 500 $m$ to more than 2,400 m (Zikán and Zikán 1940). Zikán and Zikán (1968) listed 125 species from 33 genera: Hemileucinae, 70 species (56\%); Ceratocampinae, 33 (26\%); Arsenurinae, 7 (6\%); Saturniinae, 12 (10\%); and Oxyteninae, $3(3 \%)$, with 28 undetermined species, totaling 153 species. However, their determinations should be revised with the current nomenclature, in order to develop an accurate survey.

As we can see, the Brazilian Saturniidae are still unsatisfactorily understood with respect to species distribution, taxonomy, and biological information (e.g., Albertoni and Duarte 2015), although some knowledge is available for species with medical or economic value (Lemaire 2002, Specht et al. 2008). Undeniably, faunal inventories are vital to understanding and monitoring local biodiversity (Silveira et al. 2010). Saturniid moths were efficiently attracted at night via light trap, and we report herein a species list from longterm survey data (more than 70 years) collected in a strategically located fragment of Atlantic Rain Forest (Boraceia Biological Station) in the state of São Paulo, southeastern Brazil.

The main objective of developing this list of species is to increase the knowledge and 
understanding of Brazilian biodiversity, allowing eventual amplification of the predictive capacity of lepidopteran fauna responses to global changes, particularly changes in land use and land cover and climate changes. The large extent of the reserve within which the Boraceia Biological Station is located, and because it contains mostly primary forest, two rare characteristics in fragments of Atlantic Rain Forest, make the biological station highly important for studies of the biodiversity of this biome. The importance of standardized local biological inventories and studies of community composition is evident, as in the case of the present study.

Longino and Colwell (1997) emphasized the importance of biological inventories for conservation purposes, since they allow descriptions and characterizations of communities in terms of species richness, abundance and complementarity with other communities. Obtaining such information is important, for example, in setting priorities for monitoring and conservation actions. The Saturniidae, which is usually prominent among the lepidopteran fauna due to the diversity and ecological importance of its members, and is commonly among the best-studied moth families in a given locality (Santos et al. 2015), has been the target of a number of previous inventories in Brazil.

\section{MATERIALS AND METHODS}

\section{STUDY AREA}

The survey of saturniid moths was conducted at the Boraceia Biological Station (BBS) $\left(23^{\circ} 39^{\prime} \mathrm{S}\right.$, $45^{\circ} 53^{\prime} \mathrm{W}$, elevation $\left.850 \mathrm{~m}\right)$, located in the municipality of Salesópolis, state of São Paulo, in southeastern Brazil. The Biological Station is managed by the Museu de Zoologia of the Universidade de São Paulo (MZSP) and has an area of 96 ha. The station is located within the largest fragment of Brazilian Atlantic Rain Forest, which includes several parks and other types of conservation units (Travassos Filho and Camargo 1958, Custodio Filho 1989) (Figure 1). The climate is wet tropical, Cfa in Köppen's classification (Köppen 1948). Measurements from 1925 to 1944 identified Boraceia as one of the most humid regions in Brazil, with a mean annual rainfall of 3,058 mm (Setzer 1946).

\section{MOTH SAMPLING}

Sampling of saturniid moths in the BBS started in 1942, with the entomologist Romualdo Ferreira D'Almeida. A few years later, the entomologists Lauro Travassos, Lauro Travassos Filho, Ernesto Xavier Rabello, and several associates continued the series, with extensive collections spanning decades (Travassos Filho and Camargo 1958). A recent inventory was conducted by the senior author, over 13 consecutive months in 2012 and 2013 (see also Table I).

Nocturnal moths were attracted and collected using mercury-vapor mixed bulbs placed near the white wall of one of the scientists' residences (Duarte et al. 2008). Specimens collected after 2004 were killed by injection of aqueous ammonia solution in the thorax. We have no records about how specimens were killed in expeditions carried out before 2004. Most specimens sampled from September 1942 to June 2013 were stored, identified and labeled with a registration number in addition to the previous labels. All records were stored in a digitalized database, which is intended to be of free public access through the World Wide Web. All material is deposited in the MZSP, but some of the specimens collected by Lauro Travassos were deposited in the Entomological Collection of the Oswaldo Cruz Institute, Rio de Janeiro, Brazil, and those species not represented in the MZSP were included in our list, as a complement to the number of saturniid species recorded for the BBS (Miranda et al. 2015). 


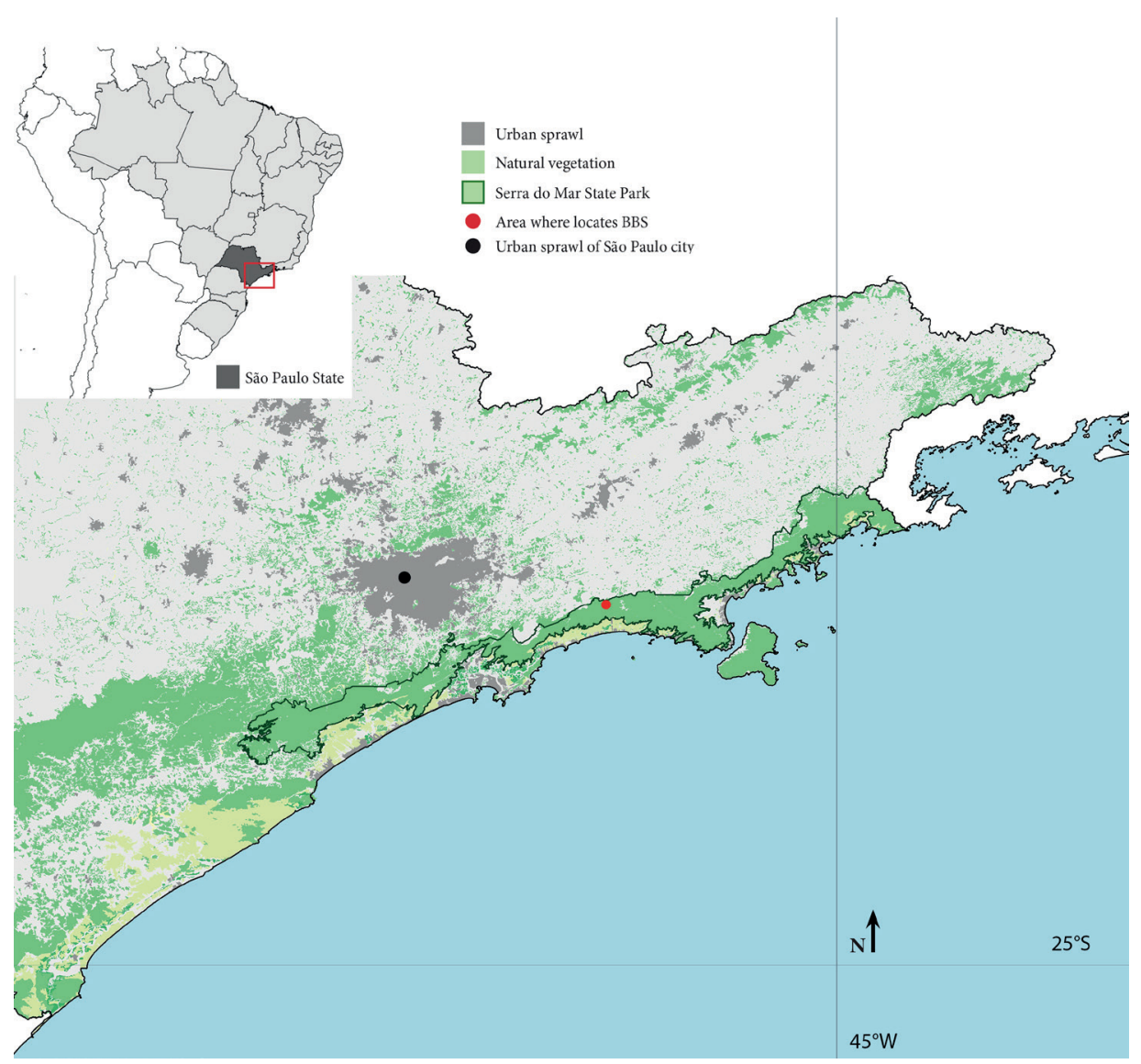

Figure 1 - Sampling area (red dot) within the largest fragment of Brazilian Atlantic rain forest.

\section{SPECIES IDENTIFICATION AND DATA ANALYSES}

Previous identifications of the specimens deposited in the MZSP collection were verified, and nomenclature was checked using Lemaire (1978, 1980, 1988, 2002). To update previous reports, we used Mielke et al. (2005), Wolfe (2005), Specht et al. (2006), and Brechlin and Meister (2011). In addition to this literature, we used the content and associated data available in the member-restricted area of the website http://www.silkmoths.bizland. com/indexos.htm. To obtain more precise identification of specimens, 63 males of several morphospecies were dissected and data concerning the genitals were compared with literature and/ or with that from previously extracted organs. Dissections were conducted as follows: the abdomen was cut at segments IV-V and placed in a boiling $10 \% \mathrm{KOH}$ solution for approximately $10 \mathrm{~min}$. The tegument and internal contents were removed, the abdomen was placed in chlorazol black solution for approximately $1 \mathrm{~min}$, and the genitals were separated from the abdomen. All parts were preserved in a container with glycerin, labeled, and given a unique code.

Most moths were pinned and dried, but a few were identified and placed in entomological envelopes, on which the sample origin and species identification were annotated.

\section{RESULTS AND DISCUSSION}

The lepidopteran collection of the MZSP hosts 6,288 specimens of Saturniidae $(5,735$ males, 552 females, and one gynandromorph) captured at the BBS between 1942 and 2013. More than 
TABLE I

Months and years with records of Saturniidae (Lepidoptera) from the Boraceia Biological Station, São Paulo, Brazil.

\begin{tabular}{|c|c|c|c|c|c|c|c|c|c|c|c|c|}
\hline Years & Jan & Feb & Mar & Apr & May & Jun & Jul & Aug & Sep & Oct & Nov & Dec \\
\hline 1942 & & $\mathrm{X}$ & & $X$ & & & & & $\mathrm{X}$ & & $X$ & $X$ \\
\hline 1943 & & & & & & & & & & & & $X$ \\
\hline 1946 & & & & & & & $X$ & & & & & \\
\hline 1947 & & & & & & & & & $X$ & & $X$ & $X$ \\
\hline 1948 & $X$ & $X$ & $X$ & $X$ & $X$ & $X$ & $X$ & $X$ & $X$ & $X$ & $X$ & $X$ \\
\hline 1949 & $X$ & $X$ & $X$ & $X$ & $\mathrm{X}$ & $X$ & $X$ & $\mathrm{X}$ & $X$ & $X$ & $X$ & $X$ \\
\hline 1950 & $X$ & $X$ & $X$ & & & & & $X$ & $X$ & & & \\
\hline 1951 & & & $X$ & & & & & & & & $X$ & \\
\hline 1952 & $X$ & & & & $X$ & $X$ & & & & & $X$ & \\
\hline 1953 & & & & & & & & & & $X$ & & \\
\hline 1954 & & $X$ & & $\mathrm{X}$ & & $X$ & $X$ & $X$ & $X$ & $X$ & & \\
\hline 1956 & & & & & & & & & $X$ & $X$ & & \\
\hline 1957 & $X$ & & $X$ & $X$ & & & & & & $X$ & $X$ & \\
\hline 1958 & & & $X$ & & & & & & $X$ & & $X$ & $X$ \\
\hline 1959 & & $X$ & $X$ & & & $X$ & $X$ & & $X$ & & $X$ & \\
\hline 1960 & & & & & & & & & & $X$ & & \\
\hline 1961 & & & & & & & & $X$ & & & & \\
\hline 1962 & $X$ & & & $X$ & & & $X$ & $X$ & $X$ & $X$ & $X$ & $X$ \\
\hline 1963 & & $X$ & $X$ & & & $X$ & & & $\mathrm{X}$ & & & \\
\hline 1964 & $X$ & $X$ & & & & & & & & $X$ & $X$ & $X$ \\
\hline 1965 & $X$ & $X$ & $X$ & $\mathrm{X}$ & $X$ & $X$ & $X$ & $X$ & $X$ & $X$ & $X$ & $X$ \\
\hline 1966 & $X$ & $X$ & $X$ & & $X$ & $X$ & $X$ & $X$ & $X$ & $X$ & $X$ & $X$ \\
\hline 1967 & & $X$ & $X$ & $X$ & & & $X$ & $X$ & $X$ & $X$ & $X$ & $X$ \\
\hline 1968 & $X$ & $X$ & $X$ & $\mathrm{X}$ & $X$ & & & $X$ & $X$ & $X$ & $X$ & $X$ \\
\hline 1969 & $X$ & $X$ & & $\mathrm{X}$ & & & $X$ & $X$ & & & & \\
\hline 1970 & & & & & & & & & & $X$ & & \\
\hline 1983 & & & & & & & & & & $X$ & & \\
\hline 1985 & $X$ & & & & & & & & & $X$ & & \\
\hline 1987 & & & & & & & & & & $X$ & & \\
\hline 1989 & & & & & & & & & & $\mathrm{X}$ & & \\
\hline 1991 & & & & & & & & & & $X$ & & \\
\hline 1995 & & & & & & & & & & $X$ & & \\
\hline 1997 & & & & $X$ & & & & & & & & \\
\hline 1999 & & & & $X$ & & & & & & & & \\
\hline 2000 & & & & & & & & & $X$ & $X$ & $X$ & \\
\hline 2001 & & $X$ & & $X$ & & & & $X$ & $X$ & $X$ & & \\
\hline 2002 & & & $X$ & & & & & & & $X$ & & \\
\hline 2003 & & & & $X$ & & & & & & & & \\
\hline 2004 & & & & $X$ & $X$ & & & & & & & \\
\hline 2008 & & & & & & & & & $X$ & & & \\
\hline 2010 & & & & & & & & & $X$ & & & \\
\hline 2012 & & $X$ & $X$ & $X$ & X & $X$ & $X$ & $X$ & $X$ & $X$ & $X$ & $\mathrm{X}$ \\
\hline 2013 & $X$ & $\mathrm{X}$ & $\mathrm{X}$ & & & $\mathrm{X}$ & & & & & & \\
\hline Total* & 13 & 16 & 15 & 16 & 8 & 10 & 11 & 13 & 20 & 24 & 17 & 13 \\
\hline
\end{tabular}

*Number of campaigns with monthly sampling between 1942 and 2013. 
$94 \%$ of the specimens examined were identified to the species level, and consisted of 43 genera and 126 species. The greatest abundance and number of species were observed for Hemileucinae, with 3,645 specimens $(58 \%)$ of 77 species $(61.1 \%)$, followed by Ceratocampinae with 1,298 specimens (20.6\%) of 23 species (18.4\%), Arsenurinae with 659 specimens $(10.5 \%)$ of 14 species (11.2\%), Saturniinae with 557 specimens (8.9\%) of 10 species $(7.9 \%)$, and Oxyteninae with 129 specimens $(2.1 \%)$ of two species $(1.6 \%)$ (Tables II and III). Besides the species deposited at MZSP, Miranda et al. (2015) recorded seven other species (one Arsenurinae, three Ceratocampinae, and three Hemileucinae, also listed in Table III) belonging to three genera from the BBS and apparently deposited only in the Entomological Collection of the Oswaldo Cruz Institute. Therefore, a total of 46 genera and 133 species are recorded from this biological station.

The distribution of the saturniid species among subfamilies in the BBS follows the pattern in most South American surveys (Ecuador: Racheli and Racheli 2005, 2006, Brazil: Marinoni et al. 1997, Camargo and Becker 1999, Nunes et al. 2004, Prestes et al. 2009, Siewert et al. 2010). Hemileucinae is the most speciose subfamily, followed by Ceratocampinae, Arsenurinae, Saturniinae, and Oxyteniinae (not infrequently, surveys do not include this subfamily because it has been raised to family rank). Worldwide, Hemileucinae is the subfamily with the largest number of species; Saturniinae, the only subfamily distributed worldwide, is next in species richness. However, although this pattern has also been observed in the Brazilian Cerrado, Camargo and Becker (1999) demonstrated that, as a percentage, Ceratocampinae and Arsenurinae together amount to almost the same proportion as Hemileucinae in this biome (48.2\% Hemileucinae vs. $47.0 \%$ Ceratocampinae plus Arsenurinae). They explained this importance of Ceratocampinae and Arsenurinae in the Cerrado by the biology of these moths. It seems that the caterpillars, which bury in the soil to pupate, have higher survival in environments with a pronounced dry season.

The most abundant genera with the most species in the BBS belonged to the subfamily Hemileucinae. The genus Hylesia Hübner, [1820] was represented by 1,433 specimens in 17 species, including Hylesia sp. 1, sp. 2, and sp. 3. The next most speciose genera were Automeris Hübner, [1819] (Hemileucinae) with 404 specimens from nine species, and Dirphiopsis Bouvier, 1928 with 266 specimens from seven species. Dirphia Hübner, [1819], with six species, was the second most abundant genus with 432 specimens. Rothschildia Grote, 1897 (Saturniinae) was the only genus not belonging to Hemileucinae to be represented by six species, with 226 specimens.

The genus Hylesia is usually markedly dominant in surveys of Saturniidae in Brazil. In Paraná and Rio Grande do Sul, for example, 14 (16.3\% of all species) and nine (8\%) species of this genus were recorded, respectively. For BBS, 17 species (13.5\% of all species) were recorded, including three morphospecies, in addition to a set of 40 specimens identified only at the genus level.

Hylesia is among the genera with the most complex taxonomy in Saturniidae due to the its phenotypic homogeneity and wide geographic distribution, covering the entire Neotropical region, from Mexico to Argentina (Lemaire 2002). Knowing that this genus is one of the most problematic in the family, the remarkable density of species and specimens sampled in the BBS makes this biological station a promising area for further studies on these saturniids. Dissections of the genitalia from 26 specimens showed that it is difficult to use the information from this part of the body for species separation (Wheeler 2008, Schlik-Steiner et al. 2010). Studies involving different tools to contribute to the delimitation of species of the genus are extremely important, both 
TABLE II

Number of species and individuals of all genera in each subfamily of Saturniidae, collected from the Boraceia Biological Station between 1942 and 2013. Gyn= Gynandromorph.

\begin{tabular}{|c|c|c|c|c|c|c|}
\hline & \multirow{2}{*}{ Subfamilies /Genera } & \multirow{2}{*}{ Species number } & \multicolumn{4}{|c|}{ Individuals } \\
\hline & & & Female & Male & Gyn & Total \\
\hline 1 & Arsenurinae & 15 & 42 & 617 & & 659 \\
\hline 1 & Arsenura & 4 & 6 & 163 & & 169 \\
\hline 2 & Copiopteryx & 3 & 18 & 194 & & 212 \\
\hline 3 & Dysdaemonia** & 1 & - & - & & - \\
\hline 4 & Loxolomia & 1 & 2 & 9 & & 11 \\
\hline 5 & Paradaemonia & 4 & 5 & 80 & & 85 \\
\hline 6 & Rhescyntis & 1 & 0 & 13 & & 13 \\
\hline 7 & Titaea & 1 & 11 & 158 & & 169 \\
\hline 2 & Ceratocampinae & 26 & 61 & 1236 & 1 & 1298 \\
\hline 8 & Adeloneivaia & 4 & 10 & 160 & & 170 \\
\hline 9 & Adelowalkeria & 2 & 4 & 187 & & 191 \\
\hline 10 & Almeidella & 1 & 2 & 53 & & 55 \\
\hline 11 & Cicia & 2 & 1 & 13 & & 14 \\
\hline 12 & Citheronia & 2 & 3 & 39 & 1 & 43 \\
\hline 13 & Eacles & 4 & 12 & 345 & & 357 \\
\hline 14 & Neorcarnegia & 1 & 0 & 1 & & 1 \\
\hline 15 & Oiticella & 2 & 2 & 46 & & 48 \\
\hline 16 & Othorene & 2 & 16 & 255 & & 271 \\
\hline 17 & Procitheronia & 2 & 6 & 106 & & 112 \\
\hline 18 & Ptiloscola** & 1 & - & - & & - \\
\hline 19 & Schausiella & 1 & 0 & 9 & & 9 \\
\hline 20 & Scolesa** & 1 & - & - & & - \\
\hline 21 & Syssphinx & 1 & 5 & 22 & & 27 \\
\hline 3 & Hemileucinae & 80 & 394 & 3251 & & 3645 \\
\hline 22 & Austrolippa & 2 & 6 & 11 & & 17 \\
\hline 23 & Automerella & 3 & 3 & 23 & & 26 \\
\hline 24 & Automeris & 9 & 51 & 353 & & 404 \\
\hline 25 & Automeropsis & 1 & 0 & 1 & & 1 \\
\hline 26 & Callodirphia & 1 & 2 & 0 & & 2 \\
\hline 27 & Catacantha & 2 & 3 & 15 & & 18 \\
\hline 28 & Cerodirphia & 5 & 20 & 143 & & 163 \\
\hline 29 & Dirphia & 7 & 26 & 406 & & 432 \\
\hline 30 & Dirphiopsis & 7 & 19 & 247 & & 266 \\
\hline 31 & Gamelia & 2 & 3 & 70 & & 73 \\
\hline 32 & Hidripa & 2 & 16 & 148 & & 164 \\
\hline 33 & Hylesia & 16 & 92 & 1341 & & 1433 \\
\hline 34 & Hyperchiria & 1 & 3 & 46 & & 49 \\
\hline 35 & Hyperchirioides & 1 & 3 & 4 & & 7 \\
\hline 36 & Leucanella & 4 & 44 & 27 & & 71 \\
\hline 37 & Lonomia & 2 & 64 & 126 & & 190 \\
\hline 38 & Molippa & 1 & 4 & 85 & & 89 \\
\hline 39 & Periga & 6 & 8 & 46 & & 54 \\
\hline 40 & Prohylesia & 1 & 0 & 8 & & 8 \\
\hline 41 & Pseudautomeris & 5 & 27 & 139 & & 166 \\
\hline 42 & Pseudodirphia & 1 & 0 & 1 & & 1 \\
\hline 43 & Travassosula & 1 & 0 & 11 & & 11 \\
\hline 4 & Oxyteninae & 2 & 3 & 126 & & 129 \\
\hline 44 & Oxytenis & 2 & 3 & 126 & & 129 \\
\hline 5 & Saturniinae & 10 & 52 & 505 & & 557 \\
\hline 45 & Copaxa & 4 & 29 & 302 & & 331 \\
\hline 46 & Rothschildia & 6 & 23 & 203 & & 226 \\
\hline & Total & 133 & 552 & 5735 & 1 & 6288 \\
\hline
\end{tabular}

** Genera listed in Miranda et al. (2015). 
TABLE III

Species of Saturniidae (Lepidoptera) collected between 1942 and 2013 from the Boraceia Biological Station, São Paulo, Brazil. Voucher material is deposited in the MZSP collection or was listed by Miranda et al. (2015). Gyn = Gynandromorph.

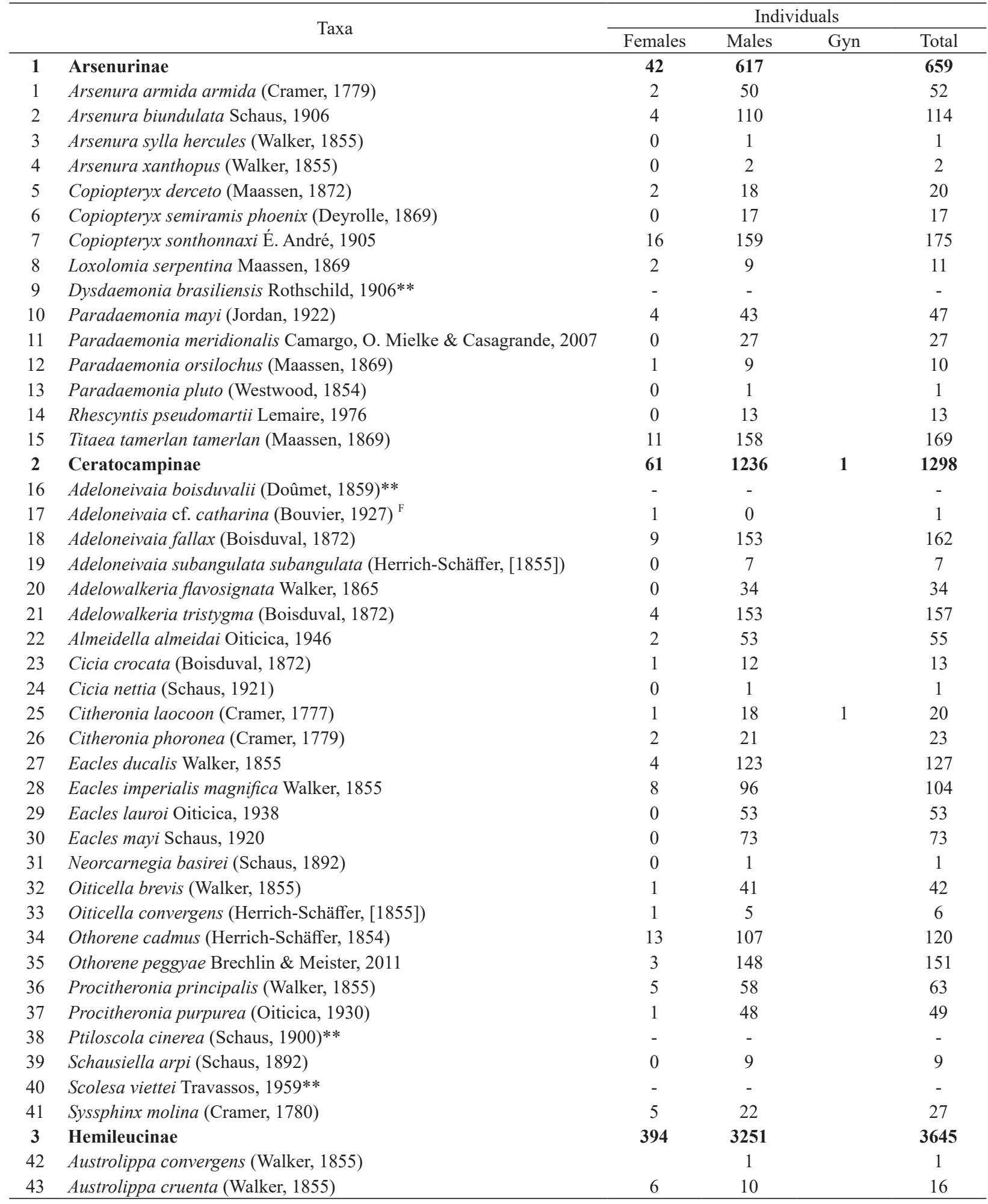


TABLE III (continuation)

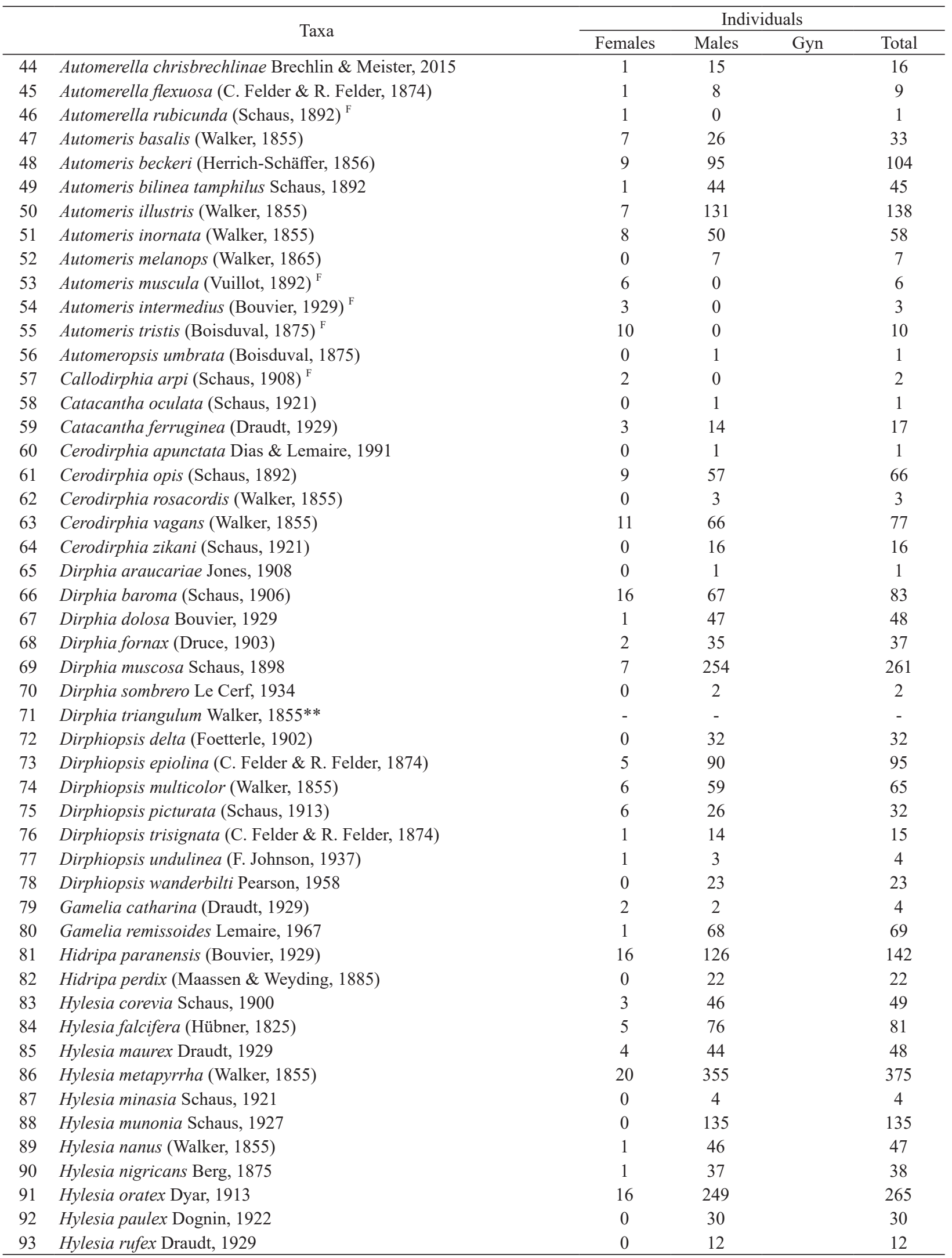


TABLE III (continuation)

\begin{tabular}{|c|c|c|c|c|c|}
\hline & \multirow{2}{*}{ Taxa } & \multicolumn{4}{|c|}{ Individuals } \\
\hline & & Females & Males & Gyn & Total \\
\hline 94 & Hylesia scortina Draudt, 1929 & 5 & 111 & & 116 \\
\hline$*$ & Hylesia sp. & 29 & 11 & & 40 \\
\hline 95 & Hylesia sp. 1 & 0 & 118 & & 118 \\
\hline 96 & Hylesia sp. 2 & 0 & 3 & & 3 \\
\hline 97 & Hylesia sp. 3 & 0 & 11 & & 11 \\
\hline 98 & Hylesia vindex Dyar, 1913 & 8 & 53 & & 61 \\
\hline 99 & Hyperchiria incisa incisa Walker, 1855 & 3 & 46 & & 49 \\
\hline 100 & Hyperchirioides bulaea (Maassen \& Weyding, 1885) & 3 & 4 & & 7 \\
\hline 101 & Leucanella gibbosa (Conte, 1906) & 21 & 26 & & 47 \\
\hline 102 & Leucanella janeira (Westwood, 1854) & 8 & 1 & & 9 \\
\hline 103 & Leucanella memusae gardineri Lemaire, 1973** & - & - & & - \\
\hline 104 & Leucanella viridescens viridescens (Walker, 1855) ${ }^{\mathrm{F}}$ & 15 & 0 & & 15 \\
\hline 105 & Lonomia antoniae Brechlin \& Meister, 2015 & 16 & 68 & & 84 \\
\hline 106 & Lonomia cf. obliqua Walker, 1855 & 48 & 58 & & 106 \\
\hline 107 & Molippa sabina Walker, 1855 & 4 & 85 & & 89 \\
\hline 108 & Periga acuta C. Mielke \& Meister, 2013 & 0 & 2 & & 2 \\
\hline 109 & Periga cf. intervales C. Mielke, Joerke, Miranda \& Costa, 2017 & 0 & 3 & & 3 \\
\hline 110 & Periga circumstans Walker, 1855 & 3 & 12 & & 15 \\
\hline 111 & Periga falcata Walker, 1855 & 5 & 7 & & 12 \\
\hline 112 & Periga sp. 1 & 0 & 10 & & 10 \\
\hline 113 & Periga sp. 2 & 0 & 12 & & 12 \\
\hline 114 & Prohylesia zikani Draudt, 1929 & 0 & 8 & & 8 \\
\hline 115 & Pseudautomeris brasiliensis (Walker, 1855) & 10 & 38 & & 48 \\
\hline 116 & Pseudautomeris coronis (Schaus, 1913) & 9 & 56 & & 65 \\
\hline 117 & Pseudautomeris grammivora (Jones, 1908) ${ }^{\mathrm{F}}$ & 2 & 0 & & 2 \\
\hline 118 & Pseudautomeris hubneri (Boisduval, 1875) & 6 & 45 & & 51 \\
\hline 119 & Pseudautomeris luteata (Walker, 1865)** & - & - & & - \\
\hline 120 & Pseudodirphia catarinensis (Lemaire, 1975) & 0 & 1 & & 1 \\
\hline 121 & Travassosula subfumata (Schaus, 1921) & 0 & 11 & & 11 \\
\hline 4 & Oxyteninae & 3 & 126 & & 129 \\
\hline 122 & Oxytenis bicornis Jordan, 1924 & 3 & 85 & & 88 \\
\hline 123 & Oxytenis modaustralis Brechlin \& Meister, 2014 & 0 & 41 & & 41 \\
\hline 5 & Saturniinae & 52 & 505 & & 557 \\
\hline 124 & Copaxa canella Walker, 1855 & 23 & 209 & & 232 \\
\hline 125 & Copaxa decrescens Walker, 1855 & 0 & 35 & & 35 \\
\hline 126 & Copaxa joinvillea Schaus, 1921 & 5 & 21 & & 26 \\
\hline 127 & Copaxa mielkeorum Brechlin \& Meister, 2010 & 1 & 37 & & 38 \\
\hline 128 & Rothschildia arethusa (Walker, 1855) & 1 & 19 & & 20 \\
\hline 129 & Rothschildia aurota speculifera (Walker, 1855) & 3 & 47 & & 50 \\
\hline 130 & Rothschildia belus (Maassen, 1873) & 0 & 5 & & 5 \\
\hline 131 & Rothschildia hesperus betis (Linnaeus, 1758) & 13 & 39 & & 52 \\
\hline 132 & Rothschildia hopfferi (C. Felder \& R. Felder, 1859) & 2 & 63 & & 65 \\
\hline 133 & Rothschildia jacobaeae (Walker, 1855) & 4 & 30 & & 34 \\
\hline & Individuals (only from MZSP) & 552 & 5735 & 1 & 6288 \\
\hline & Number of species & 84 & 118 & 1 & 133 \\
\hline & $\begin{array}{l}\text { Species with no representative of the respective sex (only from } \\
\text { MZSP) }\end{array}$ & 42 & 8 & - & 126 \\
\hline
\end{tabular}

* Males and females of Hylesia sp. that were not morphospecified are not included in the total number of species.

** Species listed by Miranda et al. (2015).

${ }^{\mathrm{F}}$ Species represented only by female individuals. 
for the subgeneric categorization of the traditional taxonomy and for the systematics and use of this knowledge to elucidate the relationships among species or groups of species (R. Dell'Erba and M. Duarte, unpublished data).

Among the saturniid species of the BBS deposited in the MZSP Lepidoptera Collection, 12 are represented by singletons: two species of Arsenurinae, Arsenura sylla hercules (Walker, 1855) and Paradaemonia pluto (Westwood, 1854); three of Ceratocampinae, Adeloneivaia cf. catharina (Bouvier, 1927), Cicia nettia (Schaus, 1921), and Neorcarnegia basirei (Schaus, 1892); and seven of Hemileucinae, Austrolippa convergens (Walker, 1855), Automerella rubicunda (Schaus, 1892), Automeropsis umbrata (Boisduval, 1875), Catacantha oculata (Schaus, 1921), Cerodirphia apunctata Dias \& Lemaire, 1991, Dirphia araucaria Jones, 1908, and Pseudodirphia catarinensis (Lemaire, 1975).

Hylesia metapyrrha (Walker, 1855) was the most abundant saturniid species recorded in the BBS, with 375 specimens, followed by Hylesia oratex Dyar, 1913 with 265 specimens; Dirphia muscosa Schaus, 1898 with 261 specimens (all Hemileucinae); Copaxa canella Walker, 1855 (Saturniinae) with 232 specimens; and Lonomia cf. obliqua Walker, 1855 (Hemileucinae) with 106 specimens. In addition, 15 other species were represented by more than 100 specimens in the MZSP Collection (Table III). Only Automeris illustris (Walker, 1855), Gamelia remissoides Lemaire, 1967, and Hidripa paranensis (Bouvier, 1929) (Hemileucinae) were recorded in all months of sampling (Table IV). Five other species appear to be constant in the BBS, although they have not been recorded in one month throughout the period of sampling (Table IV): Arsenurinae: Copiopteryx sonthonnaxi É. André, 1905; Ceratocampinae: Othorene cadmus (Herrich-Schäffer, [1855]); Hemileucinae: H. metapyrrha; Oxyteninae:
Oxytenis bicornis Jordan, 1924; and Saturniinae: Copaxa canella.

\section{CONCLUSIONS}

The number of species among the subfamilies of Saturniidae recorded from the Boraceia Biological Station followed a similar pattern to that observed in most inventories conducted in Brazil and other countries of South America. Although the number of species increased sporadically with an increasing number of samples at a given location, collections from different altitudes or phytophysiognomies of the matrix region may greatly increase the species number. In total, 133 saturniid species were recorded, with no endemism to the BBS.

We found it prudent not to compare statistically our results on species richness with other surveys, because clearly the sampling efforts were not the same, and also because the phytophysiognomies are quite different from those in the BBS. The collection of Saturniidae from the BBS deposited in the MZSP is the result of more than 70 years of sampling accumulation, and thus it is not perfectly suitable for such comparisons. However, the number of species (133 species) recorded in the present study was obtained in a single sampling site (see details in the Materials and Methods section), and is comparatively high in relation to the number of species inventoried for the Brazilian Cerrado biome (202 species), the Itatiaia region (125 species), and Rio Grande do Sul (113 species), Santa Catarina (149 species), and Paraná (131 species).

The importance of the BBS for the Saturniidae assemblage of the Atlantic region of São Paulo is due especially to its location, within a context of well-preserved Atlantic Rain Forest that extends along the northern to southern coast of the state, including the Serra do Mar State Park (Figure 1). For this reason, the BBS and its facilities are located in a strategic position and are therefore highly valuable for the knowledge and conservation of the 
TABLE IV

Phenology of the species of Saturniidae recorded between 1942 and 2013 from the Boraceia Biological Station, Salesópolis, São Paulo, Brazil (based on the material deposited in the MZSP).

\begin{tabular}{|c|c|c|c|c|c|c|c|c|c|c|c|c|}
\hline Taxa & Jan & Feb & Mar & Apr & May & Jun & Jul & Aug & Sep & Oct & Nov & Dec \\
\hline \multicolumn{13}{|l|}{ Arsenurinae } \\
\hline Arsenura armida & $\mathrm{X}$ & $\mathrm{X}$ & $\mathrm{X}$ & & & & & & $\mathrm{X}$ & & & $\mathrm{X}$ \\
\hline Arsenura biundulata & & $\mathrm{X}$ & $\mathrm{X}$ & $\mathrm{X}$ & $\mathrm{X}$ & & & $\mathrm{X}$ & & & & \\
\hline Arsenura sylla & & & & & & & & $\mathrm{X}$ & & & & \\
\hline Arsenura xanthopus & & $\mathrm{X}$ & & & & & & & & & $\mathrm{X}$ & \\
\hline Copiopteryx derceto & & & & & & & $\mathrm{X}$ & $\mathrm{X}$ & $\mathrm{X}$ & $\mathrm{X}$ & & \\
\hline Copiopteryx semiramis & $\mathrm{X}$ & $\mathrm{X}$ & $\mathrm{X}$ & $\mathrm{X}$ & & & & & & & $\mathrm{X}$ & \\
\hline Copiopteryx sonthonnaxi & $\mathrm{X}$ & $\mathrm{X}$ & $\mathrm{X}$ & $\mathrm{X}$ & & $\mathrm{X}$ & $\mathrm{X}$ & $\mathrm{X}$ & $\mathrm{X}$ & $\mathrm{X}$ & $\mathrm{X}$ & $\mathrm{X}$ \\
\hline Loxolomia serpentina & $\mathrm{X}$ & $\mathrm{X}$ & $\mathrm{X}$ & & & & & & & & $\mathrm{X}$ & $\mathrm{X}$ \\
\hline Paradaemonia mayi & & & & & & & $\mathrm{X}$ & $\mathrm{X}$ & $\mathrm{X}$ & $\mathrm{X}$ & $\mathrm{X}$ & \\
\hline Paradaemonia meridionalis & $\mathrm{X}$ & $X$ & & & & & & & & $\mathrm{X}$ & $\mathrm{X}$ & $\mathrm{X}$ \\
\hline Paradaemonia orsilochus & $\mathrm{X}$ & $\mathrm{X}$ & $\mathrm{X}$ & & & & & & & & & $\mathrm{X}$ \\
\hline Paradaemonia pluto & & & & & & & & $\mathrm{X}$ & & & & \\
\hline Rhescyntis pseudomartii & $\mathrm{X}$ & $\mathrm{X}$ & $\mathrm{X}$ & & & $\mathrm{X}$ & $\mathrm{X}$ & $\mathrm{X}$ & $\mathrm{X}$ & & $\mathrm{X}$ & \\
\hline Titaea tamerlan & $\mathrm{X}$ & $\mathrm{X}$ & $\mathrm{X}$ & $\mathrm{X}$ & & & & $\mathrm{X}$ & $\mathrm{X}$ & $\mathrm{X}$ & $\mathrm{X}$ & $\mathrm{X}$ \\
\hline \multicolumn{13}{|l|}{ Ceratocampinae } \\
\hline Adeloneivaia cf. catharina & & & & & & & & & & & & $\mathrm{X}$ \\
\hline Adeloneivaia fallax & $\mathrm{X}$ & $\mathrm{X}$ & $\mathrm{X}$ & $\mathrm{X}$ & & $\mathrm{X}$ & & $\mathrm{X}$ & $\mathrm{X}$ & $\mathrm{X}$ & $\mathrm{X}$ & $\mathrm{X}$ \\
\hline Adeloneivaia subangulata & & & $\mathrm{X}$ & & & & & & & & & \\
\hline Adelowalkeria flavosignata & $\mathrm{X}$ & $\mathrm{X}$ & $\mathrm{X}$ & & & & & & & $\mathrm{X}$ & $\mathrm{X}$ & $\mathrm{X}$ \\
\hline Adelowalkeria tristygma & $\mathrm{X}$ & $\mathrm{X}$ & $\mathrm{X}$ & & & & $\mathrm{X}$ & $\mathrm{X}$ & $\mathrm{X}$ & $\mathrm{X}$ & $\mathrm{X}$ & $\mathrm{X}$ \\
\hline Almeidella almeidai & & & & & & & & $\mathrm{X}$ & $\mathrm{X}$ & $\mathrm{X}$ & & \\
\hline Cicia crocata & $\mathrm{X}$ & & $\mathrm{X}$ & $\mathrm{X}$ & & & & $\mathrm{X}$ & & & & $\mathrm{X}$ \\
\hline Cicia nettia & & & & & & & & & & & & $\mathrm{X}$ \\
\hline Citheronia laocoon & & $\mathrm{X}$ & $\mathrm{X}$ & & & & & & $\mathrm{X}$ & $\mathrm{X}$ & $\mathrm{X}$ & $\mathrm{X}$ \\
\hline Citheronia phoronea & $\mathrm{X}$ & & & & & & & & & & $\mathrm{X}$ & $\mathrm{X}$ \\
\hline Eacles ducalis & & $\mathrm{X}$ & & & & & & & $\mathrm{X}$ & $\mathrm{X}$ & $\mathrm{X}$ & $\mathrm{X}$ \\
\hline Eacles imperialis & $\mathrm{X}$ & $\mathrm{X}$ & $\mathrm{X}$ & & & & & & $\mathrm{X}$ & $\mathrm{X}$ & $\mathrm{X}$ & \\
\hline Eacles lauroi & & & & & & & $\mathrm{X}$ & $\mathrm{X}$ & $\mathrm{X}$ & & & \\
\hline Eacles mayi & & & & & & & & $\mathrm{X}$ & $\mathrm{X}$ & $\mathrm{X}$ & & \\
\hline Neorcarnegia basirei & & & $\mathrm{X}$ & & & & & & & & & \\
\hline Oiticella brevis & $\mathrm{X}$ & $\mathrm{X}$ & $\mathrm{X}$ & & & & & $\mathrm{X}$ & $\mathrm{X}$ & $\mathrm{X}$ & $X$ & $\mathrm{X}$ \\
\hline Oiticella convergens & $\mathrm{X}$ & & $\mathrm{X}$ & $\mathrm{X}$ & & & $\mathrm{X}$ & & & $\mathrm{X}$ & & \\
\hline Othorene cadmus & $\mathrm{x}$ & $\mathrm{X}$ & $\mathrm{X}$ & $\mathrm{X}$ & & $\mathrm{X}$ & $\mathrm{X}$ & $\mathrm{X}$ & $\mathrm{X}$ & $\mathrm{X}$ & $\mathrm{X}$ & $\mathrm{X}$ \\
\hline Othorene peggyae & $\mathrm{X}$ & $\mathrm{X}$ & $\mathrm{X}$ & & & & & $\mathrm{X}$ & $\mathrm{X}$ & $\mathrm{X}$ & $\mathrm{X}$ & $\mathrm{X}$ \\
\hline Procitheronia principalis & $\mathrm{X}$ & $\mathrm{X}$ & $\mathrm{X}$ & & & & & & $\mathrm{X}$ & $\mathrm{X}$ & $\mathrm{X}$ & $\mathrm{X}$ \\
\hline Procitheronia purpurea & & & & & & & & & $X$ & $\mathrm{X}$ & & \\
\hline Schausiella arpi & $\mathrm{X}$ & $\mathrm{X}$ & & & & & & & & $\mathrm{X}$ & & $\mathrm{X}$ \\
\hline
\end{tabular}


TABLE IV (continuation)

\begin{tabular}{|c|c|c|c|c|c|c|c|c|c|c|c|c|}
\hline Taxa & Jan & Feb & Mar & Apr & May & Jun & Jul & Aug & Sep & Oct & Nov & Dec \\
\hline Syssphinx molina & $\mathrm{X}$ & $\mathrm{X}$ & $\mathrm{X}$ & & & & & & $\mathrm{X}$ & $\mathrm{X}$ & $\mathrm{X}$ & $\mathrm{X}$ \\
\hline \multicolumn{13}{|l|}{ Hemileucinae } \\
\hline Austrolippa convergens & & & & X & & & & & & & & \\
\hline Austrolippa cruenta & & $\mathrm{X}$ & X & & $X$ & & $X$ & $\mathrm{X}$ & $\mathrm{X}$ & $X$ & & \\
\hline Automerella chrisbrechlinae & $\mathrm{X}$ & $\mathrm{X}$ & & & & & $\mathrm{X}$ & $\mathrm{X}$ & & & & \\
\hline Automerella flexuosa & $\mathrm{x}$ & $\mathrm{X}$ & & & & & & & & & & \\
\hline Automerella rubicunda & & & & & & & $\mathrm{X}$ & & & & & \\
\hline Automeris basalis & & & & & & & $\mathrm{X}$ & $\mathrm{X}$ & $\mathrm{X}$ & $\mathrm{X}$ & & \\
\hline Automeris beckeri & & & & & & & $\mathrm{X}$ & $\mathrm{X}$ & $\mathrm{X}$ & $\mathrm{X}$ & & \\
\hline Automeris bilinea & $\mathrm{X}$ & & $\mathrm{X}$ & $\mathrm{X}$ & & $\mathrm{X}$ & & $\mathrm{X}$ & & $\mathrm{x}$ & $\mathrm{X}$ & $\mathrm{X}$ \\
\hline Automeris illustris & $\mathrm{X}$ & $\mathrm{X}$ & $\mathrm{X}$ & $\mathrm{X}$ & $\mathrm{X}$ & $\mathrm{X}$ & $\mathrm{X}$ & $\mathrm{X}$ & $\mathrm{X}$ & $\mathrm{x}$ & $\mathrm{x}$ & $\mathrm{X}$ \\
\hline Automeris inornata & & & & & & & $\mathrm{X}$ & $\mathrm{X}$ & $\mathrm{X}$ & & & \\
\hline Automeris melanops & & $\mathrm{X}$ & $\mathrm{X}$ & & & & & & $\mathrm{X}$ & & & \\
\hline Automeris muscula & $\mathrm{X}$ & $\mathrm{X}$ & & & & & & $\mathrm{X}$ & $\mathrm{X}$ & & & \\
\hline Automeris intermedius & & $\mathrm{X}$ & & & & & & & $\mathrm{X}$ & $\mathrm{X}$ & & \\
\hline Automeris tristis & $\mathrm{X}$ & $\mathrm{X}$ & $\mathrm{X}$ & & & & & $\mathrm{X}$ & $\mathrm{X}$ & & & \\
\hline Automeropsis umbrata & & & & & & & & & $\mathrm{X}$ & & & \\
\hline Callodirphia arpi & & & & $\mathrm{X}$ & & $\mathrm{X}$ & & & & & & \\
\hline Catacantha oculata & $\mathrm{X}$ & & & & & & & & & & & \\
\hline Catacantha ferruginea & $\mathrm{X}$ & $\mathrm{X}$ & $\mathrm{X}$ & & & & $\mathrm{X}$ & $\mathrm{X}$ & & $\mathrm{X}$ & & \\
\hline Cerodirphia apunctata & $\mathrm{X}$ & & & & & & & & & & & \\
\hline Cerodirphia opis & $\mathrm{X}$ & $\mathrm{X}$ & & $\mathrm{X}$ & $\mathrm{X}$ & $\mathrm{X}$ & $\mathrm{X}$ & & & & & $\mathrm{X}$ \\
\hline Cerodirphia rosacordis & & & & & & & & & & & $\mathrm{X}$ & $\mathrm{X}$ \\
\hline Cerodirphia vagans & & & $\mathrm{X}$ & $\mathrm{X}$ & $\mathrm{X}$ & $\mathrm{X}$ & $\mathrm{X}$ & $\mathrm{X}$ & $\mathrm{X}$ & $\mathrm{x}$ & $\mathrm{X}$ & $\mathrm{X}$ \\
\hline Cerodirphia zikani & & & & & & $\mathrm{X}$ & $\mathrm{X}$ & & & & & \\
\hline Dirphia araucariae & & & & & & $\mathrm{X}$ & & & & & & \\
\hline Dirphia baroma & & & & $\mathrm{X}$ & $X$ & $\mathrm{X}$ & $\mathrm{X}$ & $\mathrm{X}$ & & & & \\
\hline Dirphia dolosa & & & & & & $\mathrm{X}$ & $\mathrm{X}$ & $\mathrm{X}$ & $\mathrm{X}$ & & & \\
\hline Dirphia fornax & $\mathrm{X}$ & $\mathrm{X}$ & $\mathrm{X}$ & & & & & & & & & $\mathrm{X}$ \\
\hline Dirphia muscosa & $\mathrm{X}$ & $\mathrm{X}$ & & & $\mathrm{X}$ & $\mathrm{X}$ & $\mathrm{X}$ & $\mathrm{X}$ & $\mathrm{X}$ & $\mathrm{X}$ & $\mathrm{X}$ & $\mathrm{X}$ \\
\hline Dirphia sombrero & & & & & & $\mathrm{X}$ & & $\mathrm{X}$ & & & & \\
\hline Dirphiopsis delta & & & & $\mathrm{X}$ & $\mathrm{X}$ & $\mathrm{X}$ & $\mathrm{X}$ & & & & & \\
\hline Dirphiopsis epiolina & & & & $\mathrm{X}$ & & $\mathrm{X}$ & $\mathrm{X}$ & $\mathrm{X}$ & $\mathrm{X}$ & & & \\
\hline Dirphiopsis multicolor & $\mathrm{X}$ & $\mathrm{X}$ & & $\mathrm{X}$ & $\mathrm{X}$ & & $\mathrm{X}$ & $\mathrm{X}$ & $\mathrm{X}$ & $\mathrm{X}$ & $\mathrm{X}$ & $\mathrm{X}$ \\
\hline Dirphiopsis picturata & & & & & & $\mathrm{X}$ & $\mathrm{X}$ & $\mathrm{X}$ & $\mathrm{X}$ & & & \\
\hline Dirphiopsis trisignata & $\mathrm{X}$ & $\mathrm{X}$ & $\mathrm{X}$ & & & & & & & & & \\
\hline Dirphiopsis undulinea & & & & & & $\mathrm{X}$ & $X$ & & & & & \\
\hline Dirphiopsis wanderbilti & & & & & $X$ & $\mathrm{X}$ & $\mathrm{X}$ & $\mathrm{X}$ & $\mathrm{X}$ & & & \\
\hline Gamelia catharina & & & & & & & $\mathrm{X}$ & $\mathrm{X}$ & & & & $\mathrm{X}$ \\
\hline
\end{tabular}


TABLE IV (continuation)

\begin{tabular}{|c|c|c|c|c|c|c|c|c|c|c|c|c|}
\hline Taxa & Jan & Feb & Mar & Apr & May & Jun & Jul & Aug & Sep & Oct & Nov & Dec \\
\hline Gamelia remissoides & $\mathrm{X}$ & $X$ & $\mathrm{X}$ & $\mathrm{X}$ & $\mathrm{X}$ & $\mathrm{X}$ & $\mathrm{X}$ & $\mathrm{X}$ & $X$ & $\mathrm{X}$ & $\mathrm{X}$ & $\mathrm{X}$ \\
\hline Hidripa paranensis & $\mathrm{X}$ & $\mathrm{X}$ & $\mathrm{X}$ & $\mathrm{X}$ & $\mathrm{X}$ & $\mathrm{X}$ & $\mathrm{X}$ & $\mathrm{X}$ & $\mathrm{X}$ & $\mathrm{X}$ & $\mathrm{X}$ & $\mathrm{X}$ \\
\hline Hidripa perdix & & & & $\mathrm{X}$ & $\mathrm{X}$ & $\mathrm{X}$ & $\mathrm{X}$ & $\mathrm{X}$ & & & & \\
\hline Hylesia corevia & & & $\mathrm{X}$ & $\mathrm{X}$ & $\mathrm{X}$ & & & & & & & \\
\hline Hylesia falcifera & $\mathrm{X}$ & $\mathrm{X}$ & $\mathrm{X}$ & $\mathrm{X}$ & & $\mathrm{X}$ & $\mathrm{X}$ & $\mathrm{X}$ & & & & \\
\hline Hylesia maurex & & & $\mathrm{X}$ & $\mathrm{X}$ & $\mathrm{X}$ & & $\mathrm{X}$ & & & & & $\mathrm{X}$ \\
\hline Hylesia metapyrrha & $\mathrm{X}$ & $\mathrm{X}$ & $\mathrm{X}$ & $\mathrm{X}$ & $\mathrm{X}$ & $\mathrm{X}$ & & $\mathrm{X}$ & $\mathrm{X}$ & $\mathrm{X}$ & $\mathrm{X}$ & $\mathrm{X}$ \\
\hline Hylesia minasia & & & & & & $\mathrm{X}$ & $\mathrm{X}$ & & & & & \\
\hline Hylesia munonia & & & $\mathrm{X}$ & $\mathrm{X}$ & $\mathrm{X}$ & $\mathrm{X}$ & & & & & & \\
\hline Hylesia nanus & $\mathrm{X}$ & $\mathrm{X}$ & $\mathrm{X}$ & $\mathrm{X}$ & & $\mathrm{X}$ & $\mathrm{X}$ & & $\mathrm{X}$ & $\mathrm{X}$ & $\mathrm{X}$ & $\mathrm{X}$ \\
\hline Hylesia nigricans & $\mathrm{X}$ & $\mathrm{X}$ & $\mathrm{X}$ & & & & & & & & & \\
\hline Hylesia oratex & & $\mathrm{X}$ & $\mathrm{X}$ & $\mathrm{X}$ & & & & & & & & \\
\hline Hylesia paulex & $\mathrm{X}$ & $\mathrm{X}$ & $\mathrm{X}$ & $\mathrm{X}$ & $\mathrm{X}$ & & & & & & $\mathrm{X}$ & $\mathrm{X}$ \\
\hline Hylesia rufex & & & & & $\mathrm{X}$ & $\mathrm{X}$ & & & & & & \\
\hline Hylesia scortina & $\mathrm{X}$ & $\mathrm{X}$ & $\mathrm{X}$ & & & $\mathrm{X}$ & $\mathrm{X}$ & $\mathrm{X}$ & $\mathrm{X}$ & & & $\mathrm{X}$ \\
\hline Hylesia sp. & $\mathrm{X}$ & & $\mathrm{X}$ & $\mathrm{X}$ & & $\mathrm{X}$ & & & & & & \\
\hline Hylesia sp. 1 & & & $\mathrm{X}$ & $\mathrm{X}$ & $\mathrm{X}$ & & & & & & & \\
\hline Hylesia sp. 2 & & & $\mathrm{X}$ & $\mathrm{X}$ & & & & & & & & \\
\hline Hylesia sp. 3 & & & $\mathrm{X}$ & & & & & & & & & \\
\hline Hylesia vindex & & & $\mathrm{X}$ & $\mathrm{X}$ & & & & & & & $\mathrm{X}$ & $\mathrm{X}$ \\
\hline Hyperchiria incisa & $\mathrm{X}$ & $\mathrm{X}$ & $\mathrm{X}$ & & & & & $\mathrm{X}$ & $\mathrm{X}$ & $\mathrm{X}$ & & \\
\hline Hyperchirioides bulaea & $\mathrm{X}$ & $\mathrm{X}$ & & & & & & $\mathrm{X}$ & $\mathrm{X}$ & & & \\
\hline Leucanella gibbosa & $\mathrm{X}$ & $\mathrm{X}$ & & $\mathrm{X}$ & $\mathrm{X}$ & $\mathrm{X}$ & & $\mathrm{X}$ & & & $\mathrm{X}$ & $\mathrm{X}$ \\
\hline Leucanella janeira & & & & $\mathrm{X}$ & $\mathrm{X}$ & $\mathrm{X}$ & $\mathrm{X}$ & & & & & \\
\hline Leucanella viridescens & $\mathrm{X}$ & $\mathrm{X}$ & & & & & $\mathrm{X}$ & & $\mathrm{X}$ & & $\mathrm{X}$ & \\
\hline Lonomia antoniae & & $\mathrm{X}$ & $\mathrm{X}$ & $\mathrm{X}$ & & $\mathrm{X}$ & & $\mathrm{X}$ & & & & \\
\hline Lonomia cf. obliqua & $\mathrm{X}$ & $\mathrm{X}$ & $\mathrm{X}$ & & & $\mathrm{X}$ & $\mathrm{X}$ & $\mathrm{X}$ & $\mathrm{X}$ & & $\mathrm{X}$ & $\mathrm{X}$ \\
\hline Molippa sabina & $\mathrm{X}$ & $\mathrm{X}$ & $\mathrm{X}$ & & & & & $\mathrm{X}$ & $\mathrm{X}$ & $\mathrm{X}$ & & \\
\hline Periga acuta & & & $\mathrm{X}$ & & & & & & & & & \\
\hline Periga cf. intervales & & & $\mathrm{X}$ & & & $\mathrm{X}$ & & & & & & \\
\hline Periga circumstans & & & & & & & $\mathrm{X}$ & $\mathrm{X}$ & $\mathrm{X}$ & $\mathrm{X}$ & $\mathrm{X}$ & \\
\hline Periga falcata & & & & & $\mathrm{X}$ & $\mathrm{X}$ & $\mathrm{X}$ & & & & $\mathrm{X}$ & $\mathrm{X}$ \\
\hline Periga sp. 1 & & & & $\mathrm{X}$ & $\mathrm{X}$ & $\mathrm{X}$ & $\mathrm{X}$ & & & & & \\
\hline Periga sp. 2 & & & & $\mathrm{x}$ & & & & & & & $\mathrm{X}$ & $\mathrm{X}$ \\
\hline Prohylesia zikani & $\mathrm{X}$ & & & & & & & $\mathrm{X}$ & & & & \\
\hline Pseudautomeris brasiliensis & $\mathrm{X}$ & $\mathrm{X}$ & & & & $\mathrm{X}$ & $\mathrm{X}$ & $\mathrm{X}$ & $\mathrm{X}$ & $\mathrm{X}$ & & $\mathrm{X}$ \\
\hline Pseudautomeris coronis & & & $\mathrm{X}$ & $\mathrm{X}$ & & & & & & & & \\
\hline Pseudautomeris grammivora & $\mathrm{X}$ & & & & & & & & & & & \\
\hline Pseudautomeris hubneri & $\mathrm{X}$ & & & $\mathrm{X}$ & $\mathrm{X}$ & $\mathrm{X}$ & $\mathrm{X}$ & $\mathrm{X}$ & $\mathrm{X}$ & $\mathrm{X}$ & & $\mathrm{X}$ \\
\hline
\end{tabular}


TABLE IV (continuation)

\begin{tabular}{|c|c|c|c|c|c|c|c|c|c|c|c|c|}
\hline Taxa & Jan & Feb & Mar & Apr & May & Jun & Jul & Aug & Sep & Oct & Nov & Dec \\
\hline Pseudodirphia catarinensis & & & $\mathrm{X}$ & & & & & & & & & \\
\hline Travassosula subfumata & $\mathrm{X}$ & & & & & & $\mathrm{X}$ & $\mathrm{X}$ & & $\mathrm{X}$ & & \\
\hline \multicolumn{13}{|l|}{ Oxyteninae } \\
\hline Oxytenis bicornis & $\mathrm{X}$ & $\mathrm{X}$ & $\mathrm{X}$ & & $\mathrm{X}$ & $\mathrm{X}$ & $\mathrm{X}$ & $\mathrm{X}$ & $\mathrm{X}$ & $\mathrm{X}$ & $\mathrm{X}$ & $\mathrm{X}$ \\
\hline Oxytenis modaustralis & $\mathrm{X}$ & $\mathrm{X}$ & $\mathrm{X}$ & $\mathrm{X}$ & $\mathrm{x}$ & $\mathrm{X}$ & & $\mathrm{X}$ & $\mathrm{X}$ & & & \\
\hline \multicolumn{13}{|l|}{ Saturniinae } \\
\hline Copaxa canella & $\mathrm{X}$ & $\mathrm{X}$ & $\mathrm{X}$ & $\mathrm{X}$ & & $\mathrm{X}$ & $\mathrm{X}$ & $\mathrm{X}$ & $\mathrm{X}$ & $\mathrm{X}$ & $\mathrm{X}$ & $\mathrm{X}$ \\
\hline Copaxa decrescens & $\mathrm{X}$ & $\mathrm{X}$ & $\mathrm{X}$ & & & & & & $\mathrm{X}$ & $\mathrm{X}$ & $\mathrm{x}$ & \\
\hline Copaxa joinvillea & $\mathrm{X}$ & & & & & & $\mathrm{X}$ & $\mathrm{x}$ & $\mathrm{X}$ & $\mathrm{X}$ & & \\
\hline Copaxa mielkeorum & & $\mathrm{X}$ & & & & & & $\mathrm{X}$ & $\mathrm{X}$ & $\mathrm{X}$ & & \\
\hline Rothschildia arethusa & $\mathrm{X}$ & $\mathrm{X}$ & $\mathrm{X}$ & & & & & $\mathrm{x}$ & $\mathrm{x}$ & $\mathrm{X}$ & $\mathrm{X}$ & \\
\hline Rothschildia aurota & $\mathrm{X}$ & $\mathrm{X}$ & $\mathrm{x}$ & & & & & $X$ & $\mathrm{X}$ & $\mathrm{X}$ & $\mathrm{x}$ & $\mathrm{X}$ \\
\hline Rothschildia belus & & & $\mathrm{x}$ & & & & & & $\mathrm{X}$ & $\mathrm{X}$ & $\mathrm{x}$ & \\
\hline Rothschildia hesperus & $\mathrm{X}$ & $\mathrm{X}$ & $\mathrm{X}$ & $\mathrm{X}$ & & & & & & & $\mathrm{X}$ & $\mathrm{X}$ \\
\hline Rothschildia hopfferi & $\mathrm{X}$ & $\mathrm{X}$ & $\mathrm{x}$ & $\mathrm{x}$ & & & & $\mathrm{X}$ & $\mathrm{X}$ & $\mathrm{X}$ & $\mathrm{x}$ & \\
\hline Rothschildia jacobaeae & $\mathrm{X}$ & $\mathrm{X}$ & & $\mathrm{X}$ & & & $\mathrm{X}$ & $\mathrm{X}$ & $\mathrm{x}$ & $\mathrm{X}$ & $\mathrm{X}$ & X \\
\hline
\end{tabular}

biodiversity of the Atlantic Rain Forest (ChiquettoMachado et al. 2018). It is no coincidence that more than 70 years ago, in the early 1940, José Pinto da Fonseca, then head of the Entomology Division of the Biological Institute (São Paulo, SP), made several references to the importance of the BBS for knowledge of the local fauna and of its surroundings (Travassos Filho and Camargo 1958).

\section{ACKNOWLEDGMENTS}

This contribution is part of the project "Systematics, Bionomy and Evolution of Neotropical Lepidoptera" supported by the Fundação de Amparo à Pesquisa do Estado de São Paulo (FAPESP) (grant number 2002/138980, 2016/50384-8), Conselho Nacional de Desenvolvimento Científico e Tecnológico (CNPq) (grant number 563332/2010-7), and PróReitoria de Pesquisa da Universidade de São Paulo (Projeto 1). We are grateful to the Fundação de Amparo à Pesquisa do Estado de São Paulo (FAPESP) for a scholarship awarded to the senior author (grant number 2012/02441-1). MD is also grateful to Conselho Nacional de Desenvolvimento Científico e Tecnológico (grants 305905/2012-0, 311083/2015-3). We thank two anonymous reviewers for their critical reading, and Janet W. Reid for her review and corrections of the manuscript. Thanks to Renato de Oliveira e Silva, technician of the Lepidoptera Lab (Museu de Zoologia da USP), for his support in the curatorial activities of the collection.

\section{REFERENCES}

ALBERTONI FF AND DUARTE M. 2015. Immature stages of Adeloneivaia fallax (Lepidoptera: Saturniidae). Fla Entomol 98: 178-185.

BASSET Y ET AL. 2017. The Saturniidae of Barro Colorado Island, Panama: a model taxon for studying the long-term effects of climate change? Ecol Evol, p. 1-14.

BONEBRAKE TC, PONISIO LC, BOGGS CL AND EHRLICH PR. 2010. More than just indicators: A review of tropical butterfly ecology and conservation. Biol Conserv 143: 1831-1841.

BRECHLIN R AND MEISTER F. 2011. Fünfzig neue Ceratocampinae (Lepidoptera: Saturniidae). EntomoSatsphingia 4: 5-58. 
BROWN JR KS AND FREITAS AVL. 1999. Lepidoptera. In: Brandão CRF and Cancello EM (Eds), Biodiversidade do Estado de São Paulo, Brasil: Síntese do conhecimento ao final do século XX. Vol. 5. Invertebrados Terrestres, São Paulo: FAPESP, p. 225-243.

BROWN JR KS AND FREITAS AVL. 2000a. Diversidade de Lepidoptera em Santa Teresa, Espírito Santo. Boletim do Museu de Biologia Mello Leitão 11/12: 71-116.

BROWN JR KS AND FREITAS AVL. 2000b. Atlantic Forest butterflies: indicators for landscape conservation. Biotropica 32: 934-956.

BURIOL GA, ESTEFANEL V, CHAGAS AC AND EBERHARDT D. 2007. Clima e vegetação natural do Estado do Rio Grande do Sul segundo o diagrama climático de Walter e Lieth. Ciênc Florest 17: 91-100.

CAMARGO AJA AND BECKER V. 1999. Saturniidae (Lepidoptera) from the Brazilian Cerrado: composition and biogeographic relationships. Biotropica 31: 696-705.

CAMARGO AJA, DUARTE M, MIELKE CGC AND SANTOS FL. 2017. Saturniidae. In: Catálogo Taxonômico da Fauna do Brasil. PNUD. Disponível em: http://fauna. jbrj. gov.br/fauna/faunadobrasil/2727.

CHIQUETO-MACHADO PI, AMORIM FW AND DUARTE M. 2018. Long-term stability of the hawkmoth fauna (Lepidoptera, Sphingidae) in a protected area of Brazilian Atlantic Rain Forest. J Insect Conserv 22(2): 277-286.

CUSTODIO FILHO A. 1989. Flora da Estação Biológica de Boracéia - Listagem de espécies. Rev Inst Flor 1: 161-199.

DUARTE M, CARLIN LF AND MARCONATO G. 2008. Light-attracted hawkmoths (Lepidoptera: Sphingidae) of Boracéia, municipality of Salesópolis, state of São Paulo, Brazil. Check List 4: 123-136.

DUARTE M, MARCONATO G, SPECHT A AND CASAGRANDE MM. 2012. Lepidoptera. In: Rafael JA, Melo GAR, Carvalho CJB, Casari S and Constantin R (Eds), Insetos do Brasil: Diversidade e Taxonomia, Ribeirão Preto: Holos Editora, p. 625-682.

FILARDI FLR, GARCIA FCP, CARVALHO-OKANO RM AND RODRIGUES IMC. 2007. Padrões de distribuição geográfica de espécies arbóreas de Leguminosae ocorrentes no cerrado. Rev Bras Biociências 5: 1116-1118.

GILBERT LE. 1984. The biology of butterfly communities. In: Vane-Wright RI and Ackery PR (Eds), The biology of butterflies, London: Academic Press, p. 41-54.

GOLDSTEIN PZ. 2017. Diversity and significance of Lepidoptera: a phylogenetic perspective. In: Foottit RG and Adler PH (Eds), Insect Biodiversity: Science and Society, Volume 1, Oxford: J Wiley \& Sons, p. 463-495.

IBGE - INSTITUTO BRASILEIRO DE GEOGRAFIA E ESTATÍSTICA. 2004. Vegetação Brasileira - 1: 5000000. Disponível em: ftp://geoftp.ibge.gov.br/informacoes ambientais/vegetacao/mapas/brasil/biomas.pdf.
JANZEN DH. 1984. Two ways to be a tropical big moth: Santa Rosa saturniids and sphingids. Oxford Surv Evol Biol 1: 85-140.

JOHNSON SD, MORÉ M, AMORIM FW, HABER WA, FRANKIE GW, STANLEY DA, COCUCCI AA AND RAGUSO RA. 2017. The long and the short of it: a global analysis of hawkmoth pollination niches and interaction networks. Funct Ecol 31: 101-115.

KÖPPEN W. 1948. Climatologia: con un estudio de los climas de la tierra, Mexico DF: Fondo de Cultura Econômica, $478 \mathrm{p}$.

LEMAIRE C. 1978. Les Attacidae américains. The Attacidae of America (=Saturniidae). Attacinae, Neuilly-sur-Seine, Édition C. Lemaire, 238 p.

LEMAIRE C. 1980. Les Attacidae américains. The Attacidae of America (= Saturniidae). Arsenurinae, Neuilly-surSeine: Édition C. Lemaire, 199 p.

LEMAIRE C. 1988. Les Saturniidae américains. The Saturniidae of America. Los Saturnidos Americanos (= Anttacidae). Ceratocampinae, San José: Museo Nacional de Costa Rica, 480 p.

LEMAIRE C. 2002. The Saturniidae of America Hemileucinae, Keltern, Germany: Goecke \& Evers, 688 p.

LEMAIRE C AND MINET J. 1998. The Bombycoidea and their relatives. In: Kristensen NP (Ed), Handbuch der Zoologie/Handbook of Zoology. Band/volume IV Arthropoda: Insecta. Lepidoptera, Moths and Butterflies. Evolution, Systematics and Biogeography, Berlin and New York: Walter de Gruyter 1: 321-353.

LONGINO JT AND COLWELL RK. 1997. Biodiversity assessment using structured inventory: capturing the ant fauna of a tropical rain forest. Ecol Appl 7: 1263-1277.

MARINONI RC AND DUTRA RRC. 1991. Levantamento da fauna entomológica do estado do Paraná. Introdução. Situações climática e florística de oito pontos de coleta. Dados faunísticos de agosto de 1986 a julho de 1987. Rev Bras Zool 8: 31-73.

MARINONI RC, DUTRA RRC AND CASAGRANDE MM. 1997. Levantamento da fauna entomológica do Paraná. III. Saturniidae (Lepidoptera). Rev Bras Zool 14: 473-495.

MIELKE CGC, NAUMANN S AND BROSCH U. 2005. Notes on Neotropical Saturniidae: Descriptions of the females of Citheronia volcan, Adeloneivaia minuta, Kentroleuca novaholandensis, Gamelia remissoides, and Arsenura thomsoni thomsoni (Lepidoptera: Saturniidae). Nachr entomol Ver Apollo 26: 177-180.

MILLER JC. 1993. Insect natural history, multi-species interactions and biodiversity in ecosystems. Biodivers Conserv 2: 233-241.

MINET J. 1994. The Bombycoidea: phylogeny and higher classification (Lepidoptera: Glossata). Insect Syst Evol 25: 63-88. 
MIRANDA AV, SILVA MA, MIELKE CGC, CERRI D, FELIX M AND COSTA J. 2015. The Saturniidae (Lepidoptera) deposited in the Entomological Collection of the Oswaldo Cruz Institute, Oswaldo Cruz Foundation, Rio de Janeiro, Brazil, with geographic and taxonomic notes. Nachr entomol Ver Apollo 36: 136-147.

MITTER C, DAVIS DR AND CUMMINGS MP. 2017. Phylogeny and evolution of Lepidoptera. Annu Rev Entomol 62: 265-283.

MYERS N, MITTERMEIER RA, MITTERMEIER CG, FONSECA GAB AND KENT J. 2000. Biodiversity hotspots for conservation priorities. Nature 403: 853-858.

NÄSSIG WA, KITCHING IJ, PEIGLER RS AND TREADAWAY CG. 2010. The group of Cricula elaezia: Comments on synonyms and priority questions, with illustrations of barcode similarity trees, distribution maps, a revised checklist and a formerly unknown female (Lepidoptera: Saturniidae). Nachr entomol Ver Apollo 31: 145-161.

NUNES FG, PRESTES AS AND CORSEUIL E. 2004. Mariposas do gênero Rothschildia (Lepidoptera, Saturniidae) registradas para o Rio Grande do Sul. Biociências 12: 31-36.

PRESTES AS, NUNES FG AND CORSEUIL E. 2009. Arsenurinae and Ceratocampinae (Saturniidae) of Rio Grande do Sul, Brazil. J Lepid Soc 63: 214-232.

RACHELI L AND RACHELI T. 2005. An update checklist of the Saturniidae of Ecuador. Part I: Hemileucinae (Lepidoptera: Saturniidae). SHILAP Revta Lepid 33: 203 223.

RACHELI L AND RACHELI T. 2006. An update checklist of the Saturniidae of Ecuador. Part II: Arsenurinae, Ceratocampinae, Saturniinae (Lepidoptera: Saturniidae). SHILAP Revta Lepid 34: 197-211.

REGIER JC, GRANT MC, MITTER C, COOK CP, PEIGLER RS AND ROUGERIE R. 2008. Phylogenetic relationships of wild silkmoths (Lepidoptera: Saturniidae) inferred from four protein-coding nuclear genes. Syst Entomol 33: 219228.

SANTOS FL, CASAGRANDE MM AND MIELKE OHH. 2015. Saturniidae and Sphingidae (Lepidoptera, Bombycoidea) assemblage in Vossoroca, Tijucas do Sul, Paraná, Brazil. An Acad Bras Cienc 87: 843-860.

SCHLICK-STEINER BC, STEINER FM, SEIFERN B, STAUFFER C, CHRISTIAN E AND CROZIER RH. 2010. Integrative taxonomy: a multisource approach to exploring biodiversity. Annu Rev Entomol 55: 421-438.

SETZER J. 1946. Contribuição para o estudo do clima do Estado de São Paulo. Boletim do Departamento de Estradas e Rodagens do Estado de São Paulo 9/11: 1-239.
SIEWERT RR, SILVA EJE AND MIELKE CGC. 2010. Saturniidae from Santa Catarina state, Brazil, with taxonomic notes (Lepidoptera). Nachr entomol Ver Apollo 30: 215-220.

SILVEIRA LF, BEISIEGEL BM, CURCIO FF, VALDUJO PH, DIXO M, VERDADE VK, MATTOX GMT AND CUNNINGHAM PTM. 2010. What use do fauna inventories serve? Estudos Avançados 24: 173-207.

SILVEIRA NETO S AND SILVEIRA AC. 1969. Armadilha luminosa, modelo "Luiz de Queiroz". O Solo 61: 19-21.

SPECHT A, CORSEUIL E AND ABELLA HB. 2008. Lepidópteros de importância médica. Principais espécies ocorrentes no Rio Grande do Sul. Pelotas: Editora USEB, $220 \mathrm{p}$.

SPECHT A, CORSEUIL E AND FORMENTINI AC. 2005a. Lepidópteros de importância médica ocorrentes no Rio Grande do Sul - Aididae e Limacodidae. Biociências 13: 89-94.

SPECHT A, CORSEUIL E AND FORMENTINI AC. 2005b. Lepidópteros de importância médica ocorrentes no Rio Grande do Sul - Saturniidae - Hemileucinae. Biociências 13: 149-162.

SPECHT A, FORMENTINI AC AND CORSEUIL E. 2006. Biologia de Hylesia nigricans (Berg) (Lepidoptera, Saturniidae, Hemileucinae). Rev Bras Entomol 23: 248255.

ST. LAURENT RA, MIELKE CGC AND NAUMANN S. 2015. Notes on the genus Eacles Hübner, [1819] in Brazil with descriptions of the females of Eacles bertrandi Lemaire, 1981 and Eacles mayi Schaus, 1920 (Lepidoptera: Saturniidae, Ceratocampinae). Nachr entomol Ver Apollo 36: 196-207.

TRAVASSOS FILHO L AND CAMARGO HFA. 1958. A Estação Biológica de Boracéia. Arq Zool 11: 1-21.

VAN NIEUKERKEN EJ ET AL. 2011. Order Lepidoptera Linnaeus. In: Zhang ZQ (Ed), Animal biodiversity: An outline of higher level classification and survey of taxonomic richness. Zootaxa 3148: 1-237.

WHEELER QD. 2008. Undisciplined thinking: morphology and Hennig's unfinished revolution. Syst Entomol 33: 2-7.

WOLFE KL. 2005. A resurrection of Copaxa canella flavobrunnea Bouvier, 1930 and elevation to species status, with illustration of the early stages (Lepidoptera: Saturniidae). Nachr entomol Ver Apollo 26: 31-33.

ZIKÁN JF AND ZIKÁN W. 1940. Introdução à inseto-fauna do Itatiaia e da Mantiqueira. Rodriguésia 4: 155-165.

ZIKÁN JF AND ZIKÁN W. 1968. Inseto-fauna do Itatiaia e da Mantiqueira. Lepidoptera. Pesqui Agropecu Bras 3: 45-109. 